\title{
Student Involvement in Community Activities Related to Educational Programs
}

\author{
Danang Prasetyo ${ }^{1 *}$, Yoga Ardian Feriandi², Sukron Mazid ${ }^{3}$ (iD \\ ${ }^{1} M K W U$ PPKn, Sekolah Tinggi Pariwisata Ambarrukmo Yogyakarta, Yogyakarta, Indonesia \\ ${ }^{2}$ Prodi PPKn, Universitas PGRI Madiun, Madiu, Indonesia \\ ${ }^{3}$ FKIP, Universitas Tidar Magelang, Magelang, Indonesia \\ *Corresponding author: danangprasetyo@stipram.ac.id
}

\begin{abstract}
Abstrak
Pengembangan objek kajian materi pendidikan kewarganegaraan tidak terpaku di ruang kelas yang dilakukan di sekolah formal persekolahan, melainkan juga dapat dilakukan dalam aktivitas masyarakat yang dikenal dengan sosio cultural citizenship. Hal inilah yang menjadi tujuan penelitian ini dengan mendeskripsikan penerapan pendidikan kewarganegaraan dalam lingkup kemasyarakatan, yakni keterlibatan mahasiswa dari berbagai perguruan tinggi yang tergabung ke dalam Komunitas Sekolah Rakyat Atap Senja. Metode yang dugunakan adalah studi kasus pada keterlibatan mahasiswa dalam aktivitas komunitas yang berkaitan dengan program pendidikan yang dilakukan di masyarakat. Hasil dari penelitian ini menunjukan bahwa konsep pendidikan kewarganegaraan kemasyarakatan dapat dilakukan dengan melibatkan community civic education yang berkembang di masyarakat yakni Komunitas Sekolah Rakyat Atap Senja di Yogyakarta. Komunitas ini beranggotakan mahasiswa dari berbagai perguruan tinggi yang ada di Yogyakarta. Kegiatan yang dilakukan dengan memberikan pendampingan belajar dan perhatian pada perkembangan moralitas kepada anak-anak yang tidak mendapatkan pendidikan formal di sekolah. Pendanaan dari kegiatan yang dilakukan komunitas ini berasal dari iuran anggota atau yang selama ini disebut dengan relawan. Kegiatan yang dilakukan komunitas ini menjadi bukti pertisipasi warga negara muda untuk mengubah kondisi pendidikan anak-anak putus sekolah, dengan berbagai macam keterbatasan finansial yang ada. Hal inilah yang dapat di artikan sebagai bentuk civic engagement kepada negara, karena secara tidak langsung kegiatan kemasyarakatan tersebut juga akan mempengaruhi dan memperbaiki kondisi pendidikan di Indonesia.
\end{abstract}

Kata kunci: Kewarganegaraan Kemasyarakatan, Civic Engagement, Komunitas Sekolah Rakyat.

\section{Abstract}

The development of the object of study of citizenship education material is not fixed in classrooms carried out in formal schools, but can also be carried out in community activities known as socio-cultural citizenship. This is the purpose of this study by describing the application of civic education in the social sphere, namely the involvement of students from various universities who are members of the Atap Senja Community School. The method used is a case study on student involvement in community activities related to educational programs carried out in the community. The results of this study indicate that the concept of civic civic education can be carried out by involving community civic education that develops in the community, namely the Atap Senja Community School in Yogyakarta. This community consists of students from various universities in Yogyakarta. Activities carried out by providing learning assistance and attention to the development of morality for children who do not receive formal education at school. Funding for activities carried out by this community comes from membership fees or what has been called volunteers. The activities carried out by this community are proof of the participation of young citizens in changing the educational conditions of school dropouts, with various kinds of financial limitations. This can be interpreted as a form of civic engagement with the state, because indirectly these community activities will also affect and improve the conditions of education in Indonesia.

Keywords: Civic Education, Civic Engagement, People's School

$\begin{array}{ll}\text { History: } & \text { Publisher: Undiksha Press } \\ \text { Received : September 02, } 2021 & \text { Licensed: This work is licensed under } \\ \text { Revised : September 03, } 2021 & \text { a Creative Commons Attribution 3.0 License } \\ \text { Accepted : April October 14, } 2021 & \text { CC (C) (O) } \\ \text { Published : October } 25,2021 & \text { SA }\end{array}$

\section{INTRODUCTION}

Almost all countries that adhere to the notion of democracy want to develop the concept of civil society. One effort to make it happen is by teaching and implementing civic education to the community so that they have civic competencies which consist of civic knowledge, civic skills and civic disposition (Pangalila, 2017; Supriyadi, 2015). The three components incorporated in the civic competencies are important components that will shape 
citizens to carry out their rights and obligations proportionally (Soapatty, 2014; Trisiana, 2020). Thus, it can be said by equipping citizens to have civic competencies. This also directly improves Indonesia's human capital, which in fact is very necessary to support democratic life. Civic knowledge competence is related to knowledge and understanding that must be possessed by every individual, because it functions to understand the rights and obligations as citizens (Cohen et al., 2018; Nuryadi, 2020). This understanding can have a positive effect on the younger generation and an overview of active participation including the use of voting rights in the future (Torney-Purta, 2002; Torney-Purta et al., 2015). Furthermore, civic skills are skills that are developed from civic knowledge, so that the knowledge obtained becomes something meaningful to be used in dealing with problems in the life of the nation and state (Gustama, 2019). Citizenship skills are formed from the accumulation of knowledge and understanding of citizens which will be directly proportional to insight, so that they are able to form critical thinking patterns in young citizens. National Standards For Civics Framework for 1988 National Assessment of Educational Progress (NAEP) asserts that critical thinking skills as civic skills include the skills to identify, describe, describe, explain, analyze, evaluate, determine, defend opinions related to public problems (Komalasari, 2011).

The next civic competence is civic disposition, which is the third component of civic competence. These competencies arise from the accumulation process of civic knowledge and civic skills. The concept of civic disposition will always relate to the character of citizens in the public and private spheres within the scope of democracy (Suyatno \& Wantini, 2018). Civic disposition as a component of civic competence can be developed in the school, family and community environment. In the public sphere, civic disposition can be measured through the level of awareness as a citizen, obeying the law, critical thinking, politeness, the ability to be a good listener, and the ability to compromise. Whereas in the private sphere, it includes moral responsibility, discipline and upholding human dignity. Regarding civic competitions, the results of research from ICCS (International Civic and Citizenship Studies) on the condition of civic education in five countries (Indonesia, Hong Kong SAR, Republic of Korea/South Korea, Taiwan, and Thailand) stated that the results of the civic knowledge test) in Indonesia and Thailand in secondary school students is still relatively low when compared to other sample countries in Asia (Schulz et al., 2010). This is contrary to the characteristics of civic education learning that has been used in Indonesia, which places great emphasis on the knowledge aspect. If the knowledge is lacking, then of course the skill and disposition aspects will also be lacking, because the basic foundation is knowledge.

Unfortunately, currently civic education in Indonesia is still too focused on the study of schooling, different from some countries that have been able to implement civic education at the community level at large. This is considered as a form of continuum, to further clarify the meaning of the continuum of citizenship education proposed by David Kerr, he has conceptualized 3 approaches, namely (1) Education About Citizenship; (2) Education Thought Citizenship; and (3) Education For Citizenship. There are characteristics that identify the continuum of "citizenship education" as being at a maximum or minimum. The following table describes the characteristics of the minimum and maximum category differences (Kerr, 1999). The teaching of civic education in Indonesia is included in civic education, not citizenship education. Based on the context, citizenship education has a broader meaning than civic education. In Indonesia, the context of learning citizenship education is only limited to teaching in formal schools. Indonesia has not been able to include civic education in the realm outside of school. Referring to the three concepts, civic education in Indonesia still focuses on the cognitive aspect, or is only included in the education about approach (Kerr, 1999), namely citizenship education which focuses on providing students with sufficient knowledge and understanding of national history and the 
structures and processes of government and political life. Based on this simple analysis, it can be concluded that the implementation of civic education in Indonesia is currently in the minimal category.

Achieving complex educational goals cannot only rely on civic education at the formal level (curricular domain), but other domains of civic education must also be optimized (socio-cultural). The consideration is that the purpose of forming the behavior or character of citizens in terms of good and smart citizens needs to get emphasis and habituation from the family, environment, and school spheres (Lickona, 2004; Misla \& Mawardi, 2020). The formation of behavior that starts from school will continue to be continuous with life activities, not just because class hours have ended or because someone is no longer taking formal education.

In addition, character development (good and smart citizen) is not only obtained through formal education, but can also be obtained through non-formal education, namely through study groups, course institutions, and communities. In addition, the most dominant character building is through informal education, namely through education in the family and community environment independently. To build the nation's character, civic education must play a role as a curricular program in formal and non-formal educational institutions (Sofyan \& Sundawa, 2016). As a socio-cultural movement for citizenship, and as a national political education for state administrators, leaders and members of social organizations and political organizations. The three roles must be seen as a single unit, for that this paper will examine how the application of community citizenship education in community activities, namely the Atap Senja People's School Community in Yogyakarta. This community was born from the concern of young citizens to have a role in advancing education with learning assistance activities and the formation of morality for riverside children who do not take formal education.

\section{METHODS}

This type of research is descriptive research with a qualitative approach. The target of this research is to find, explore, detail and record various main things regarding the activities and activities of the Atap Senja People's School Community. The research subjects were determined by using a purposive technique, namely the determination of the subject intentionally by the researcher based on certain criteria or considerations. The characteristics or criteria of the research subjects chosen by the researchers are (1) members who know about the direct activities of the Atap Senja People's School Community; (2) administrators who are directly involved in the Atap Senja People's School Community. Based on these criteria, the subjects of this research are: (1) students who are active in the Atap Senja People's School Community; (2) the head of the Atap Senja People's School Community. The research was conducted from January 2020 to December 2020 with the location at the university where volunteers are studying and Badran Village, the location of the Atap Senja People's School Community service. Data collection techniques used in this study are: observation, interviews, and documentation. The validity of the data was checked by using triangulation technique. The data analysis technique used is inductive analysis technique, namely analysis based on the data obtained. The steps to analyze the data in this study are data reduction, unitization and categorization, displaying data, and making conclusions (Cresswell, 2012). 


\section{RESULTS AND DISCUSSION}

\section{Results}

The Atap Senja People's School (hereinafter referred to as SR Atap Senja) is the initiation of several students majoring in International Relations UPN (University of National Development) "Veterans" Yogyakarta, in collaboration with several students from other universities. It was founded in 2014 in the Badran area, Yogyakarta, then in 2015 SR Atap Senja began teaching on the banks of the Code Gondolayu River. Initially, there were only a few members of the Atap Senja People's School. However, over time and the increasing popularity of Atap Senja, this community has about 50 permanent members, plus volunteers who are quite active in every activity. Not only from UPNV Yogyakarta, members of Atap Senja are also from UNY (State University of Yogyakarta), UII (Islamic University of Indonesia), Sunan Kalijaga State Islamic University, and UGM (Gadjah Mada University). Currently, there are 84 volunteers after the opening of registration in August 2018. This number is the largest ever. The majority of volunteers are UPN Yogyakarta students, and several other campuses such as UIN Sunan Kalijaga, UNY, Sanatha Dharma, and Akprind Yogyakarta.

The purpose of the formation of this teaching community is to foster good character among the children on the banks of the river. Most of them are ignored by their parents in terms of education because their parents are busy providing for the family's economic needs. Most of their parents work late at night making it difficult to pay attention to their children in learning activities. The roof of the twilight was founded on the concern of UPN "Veteran" Yogyakarta students for riverside children, especially in terms of character education. If at school they will get knowledge, then at Atap Senja it will help shape the character of children with noble personalities. There are two places used for teaching activities, namely in Gondolayu and Badran. Teaching activities at Gondolayu are held every Tuesday, precisely after sunset or when the sun has set on the western horizon. Teaching activities at Badran are held every Wednesday at the same time.

The lecturers consisting of various majors departed from the UPNV Yogykarta Auditorium. So, they gather first to make sure if anyone has not been able to get a ride and can also go together for teachers who don't know the route yet. If there is someone whose house is near the place of teaching, they can also go directly, there is no need to gather in the auditorium first. Gathering in the auditorium is also used for briefings on what materials will be taught to children. For teaching places, Gondolayu consists of one place in the Gondolayu RW Hall. Meanwhile, Badran consists of five RTs, which are conducted in their respective RTs, namely RT 47, 48, 49, 50, and 51. Teaching is carried out in four places, because RT 50 and RT 51 are made into one place.

The source of funds for SR Atap Senja is from cash money of Rp. 2,000, which is collected at the core treasurer every time there is a teaching activity in Gondolayu or in

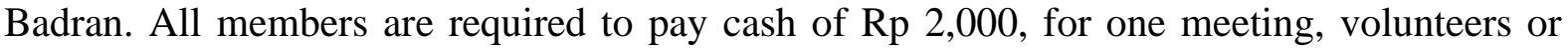
volunteers may also contribute to pay cash of $\mathrm{Rp} 2,000$. If there is a need for teaching and learning activities, we usually use the cash, then if there are outdoor activities such as semester outbounds, we usually submit a budget for these outbound activities to the head of the RW (Rukun Warga) in the area. From the SR Atap Senja itself, they did not hold a Business Fund due to limited time and difficulty coordinating members because not all members came from the same faculty or university. Atap Senja has several work programs, such as teaching activities every Tuesday night or Wednesday night (precisely on the banks of the Code Gondolayu River) and Wednesday night or Thursday night (precisely in the Badran area), the agenda for the formation of a parent committee, core meetings every 2 weeks, maintaining gathering with outside communities at least once every 3 months, and outbound activities held every semester. 
In addition, Atap Senja divides its members into several divisions. There are divisions for teaching, public relations, curriculum, and equipment. The main task of the teaching division is to teach the children under the guidance of the Badran and Kali Code Gondolayu areas, the task of the public relations (public relations) division as usual is to maintain the relationship between Atap Senja and the community or outside communities, and introduce SR Atap Senja to the wider community. Then there is the curriculum division where the main task is to arrange teaching and learning schedules and materials to be delivered, and finally there is the Equipment and Documentation division whose main task is to document every series of activities in SR Atap Senja

\section{Community Based Civic Engagement}

Citizenship education is actually given not only at the formal education level, but also to the community at the school level the nomenclature used is Civic education which means "...the foundational course work in school designed to prepare young citizens for an active role in their communities in their adult lives" (Arif, 2016). citizenship education or education for citizenship includes "...both these in-school experiences as well as out of school or nonformal/informal learning which takes place in the family, the religious organization, community organizations, the media, etc. which help to shape the totality of the citizen". So if it is associated with bureaucracy, it is more suitable to use the nomenclature of citizenship education/education for citizenship. At the philosophical conceptual level, citizenship education includes three dimensions, namely as a scientific study, as a curricular program, and as a cultural social movement of citizens. Therefore, axiologically, the existence of civic education contains 3 (three) uses, namely: facilitating the development of a body of knowledge from the knowledge system and implementation of civic education, underpinning and facilitating the development and implementation of democratic education curricular programs in schools and outside schools and framing and facilitating the development of corridors. Socio-cultural democratization process in society.

Through its epistemological activities, various concepts, principles, procedures, methods and techniques related to research, development and evaluation of civic behavior and civic culture can be built to enrich the civic education system. For example, the concept of civic culture which is publicly the basic concept of civic education in the USA. At the community level, civic culture should become a discourse and order for citizens' social and cultural interactions as a form of civil society development, one of which can be realized through civic education based on community activities. If viewed from a pedagogical and andragogic perspective, the Pancasila value system contained in civic education must be realized as a lifelong learning process for children and adults through a learning process that is concentric about Pancasila, learning through a process that reflects the soul and actualization of values in the life of the community, nation. and a religious, civilized, united, democratic, and just Indonesian state (Winataputra \& Budimansyah, 2007).

\section{Discussion}

The involvement of students in the Atap Senja People's School is a form of implementing Community citizenship education, because even though they are students, this program is carried out without any assignment from the campus. Everything they do in the school is purely because of their own desires and their concern for the condition of the community, especially in the area along the Code River, Yogyakarta, precisely in Gondolayu Village. The condition of the people in Gondolayu Village are mostly casual workers such as traders, porters, pedicab drivers, construction workers where they do not have a fixed income. Not much different from Gondolayu Village, in Badran Village the condition of the community is the same as in Gondolayu Village so that parents object if their children take 
tutoring outside of school because of the many needs, irregular income and the high cost of attending tutoring the learning process so that parents are very grateful to the roof twilight teachers because their programs help children, especially in the fields of education and character building. Parents in Kampung Badran and Kampung Gondolayu are very supportive of the Atap Senja program of activities. Of the many volunteers, apart from those who were moved by seeing the condition of the community, there were some who admitted that they joined this community because they wanted to take advantage of their free time when they were not busy with college.

In these activities, the service they provide is by teaching, although it is not always about school material but sometimes it is also inserted by other activities. In a two hour duration, Atap Senja divides the first hour to provide material about school lessons. The rest is to help do assignments and inculcate character values through stories and games. Teaching and learning sessions are held in the evening from 19:00 to 21:00 WIB. The first hour is done to deliver the material that has been prepared. Then, an hour later the volunteers helped the children teach the homework they got from school. Children respond actively and are not shy to express their opinions. Atap Senja is not only teaching academic material, but also moral lessons such as discipline and ethics which are very important for socializing in the wider community.

Before starting the activity, usually the children pray first, led by one of the children. The content of the activity is the provision of material that has been determined from the curriculum, the material can be in the form of a PowerPoint or description. After the delivery of the material by the teacher, the children will be guided to do their homework. Like children in general who get bored easily, the activities are interspersed with educational games such as guessing pictures, mentioning various kinds of animals and plants, and asking questions about the diversity of Indonesia. At Atap Senja, apart from being given scientific material as mentioned above, they are also invited to plant plants and also make crafts. After completing the activity, the children were trained to pray and shake hands with the management, members, and volunteers of the roof of the dusk as a sign of gratitude to God and to the brothers and sisters of Atap Senja. That way, they are taught about the importance of appreciating people who do well to their fellow human beings. After they shook hands, they returned to their respective homes. After that the administrators, members, and volunteers conduct an evaluation. The goal is to see and know the process that occurs in the learning process, if there is a deficiency or a problem so that it can be corrected for the next day when teaching. The sources of funds in the Roof Twilight organization are members, volunteers, and the administrators of the Twilight Roof itself.

By involving themselves in the community directly through the People's School, students get a big impact, especially in terms of increasing experience, increasing social awareness, cultivating relationships between schools and communities, and fostering student leadership and improving students' problem solving abilities, all of which is part of Civic engagement (Meyer et al., 2016). Citizen engagement (civic engagement) itself is a condition that shows that citizens individually or collectively participate actively in community life based on skills, expertise, knowledge, which are combined with values, motivation and commitment to make changes in order to improve quality people's lives for the better (Adler \& Goggin, 2005).

The fact about this engagement is corroborated by the results of interviews with volunteers who said that the members of the Atap Senja People's School consist of various majors from several different campuses. From there, the benefits of organizing will be felt, one of which is adding relationships or friends. By participating in Atap Senja, the opportunity to add friends from various majors is wide open because this community can be followed by anyone. It's not easy to stay on the Roof of Dusk. Most teachers quit halfway 
because they have to spend time with lectures and there may be other reasons why they can stop. But there are those who are loyal to contribute to the children of Atap Senja for the realization of character education. They are willing to travel tens of kilometers to teach and share knowledge with children. In principle, while students have more knowledge why not share it with others who need it. Involvement in this community does not require a cum laude GPA (Graduate Achievement Index), does not require a respected high position, and does not require university-popularity to be able to join the SR Atap Senja. With sincere capital and high will, anyone can join the Atap Senja People's School to make a small change by creating Indonesian youth with noble personalities.

Interestingly, even though some of them only intend to fill their spare time and fill their busy lives, they will get great benefits in the future. Research shows that their involvement at a young age in the community through social services will be able to make them repeat it again in the future, even if they do it forcefully they will get these benefits. Although not directly this activity is a form of engagement of young citizens (students) to the state, and the community. The Atap Senja School community collectively actively participates in the community based on expertise, knowledge combined with values, motivation and commitment to make changes in order to improve the quality of life of the community for the better.

\section{CONCLUSION}

From the results of the discussion, it can be concluded that civic education can not only be implemented in the formal school domain, but can also be implemented in the community or socio-cultural realm. In an effort to mainstream the values of Citizenship Civilization and Engagement to students, the two domains of civic education are very important and complementary. Learning Civic education at schools or universities which are usually rich in knowledge components is supported by socio-cultural civic education which is rich in skill development and disposition. It can be said that the active participation of students in various community communities, including the People's School of the roof of Senja, is a means of community citizenship education for students as a follow-up to the civic education learning that students receive in the formal education curriculum on campus. Even though this activity does not directly become a real form of implementation of community citizenship education that is able to form civic engagement of the younger generation to their country. Although it is not much, the existence of this community can certainly encourage the improvement of the quality of Indonesian citizens' resources. What's more, the students in the Atap Senja People's School are street children who have been considered to be a nuisance to public order and are even considered a lower class society and are considered a burden to the state. Thus, students who participate in the Atap Senja School Community collectively participate actively in the community based on expertise, knowledge combined with values, motivation and commitment to make changes in order to improve the quality of life of the community for the better.

\section{REFERENCES}

Adler, R. P., \& Goggin, J. (2005). What do we mean by "civic engagement"? Journal of Transformative Education, 3(3), 236-253. https://doi.org/10.1177/1541344605276792.

Arif, D. B. (2016). Pengembangan komponen kompetensi kewargaan dalam buku teks Pendidikan Kewarganegaraan SMP/MTs. Jurnal Civics: Media Kajian Kewarganegaraan, 13(1). https://doi.org/10.21831/civics.v13i1.11076. 
Cohen, A. K., Littenberg-Tobias, J., Ridley-Kerr, A., Pope, A., Stolte, L. C., \& Wong, K. K. (2018). Action civics education and civic outcomes for urban youth: An evaluation of the impact of Generation Citizen. Citizenship Teaching \& Learning, 13(3), 351-368. https://doi.org/10.2307/20054172.

Cresswell, J. W. (2012). Educational Research. Pearson.

Gustama, I. W. (2019). Penerapan Model PBL (Problem Based Learning) Untuk Meningkatkan Keterampilan Kewarganegaraan (Civic Skills) Siswa Kelas Xi IA6 Sma Negeri 1 Singaraja Tahun Pelajaran 2013/2014. Jurnal Pendidikan Kewarganegaraan Undiksha, 7(1). https://doi.org/10.23887/jpku.v7i1.22074.

Kerr, D. (1999). Citizenship education in the curriculum: An international review. School Field, 10(3/4), 5-32. https://doi.org/10.1.1.585.2377.

Komalasari, K. (2011). Kontribusi pembelajaran kontekstual untuk pengembangan kompetensi kewarganegaraan peserta didik SMP di Jabar. Mimbar: Jurnal Sosial Dan Pembangunan, 27(1), 47-55. https://media.neliti.com/media/publications/7407-IDkontribusi-pembelajaran-kontekstual-untuk-pengembangan-kompetensikewarganegaraa.pdf.

Lickona, T. (2004). Character matters: How to help our children develop good judgment, integrity, and other essential virtues. Simon and Schuster.

Meyer, C. L., Harned, M., Schaad, A., Sunder, K., Palmer, J., \& Tinch, C. (2016). Inmate Education as a Service Learning Opportunity for Students: Preparation, Benefits, and Lessons Learned. Teaching of Psychology, 43(2), 120-125. https://doi.org/10.1177/0098628316636278.

Misla, M., \& Mawardi, M. (2020). Efektifitas PBL dan Problem Solving Siswa SD Ditinjau dari Kemampuan Berpikir Kritis. Jurnal Ilmiah Sekolah Dasar, 4(1), 60-65. https://doi.org/10.23887/jisd.v4i1.24279.

Nuryadi, M. H. (2020). The Pattern of the Teaching of Multiculturalism-Based Civics Education: A Case Study at Higher Education Institutions. European Journal of Educational Research, 9(2), 799-807. https://eric.ed.gov/?id=EJ1250401.

Pangalila, T. (2017). Peningkatan Civic Disposition Siswa Melalui Pembelajaran Pendidikan Kewarganegaraan (PKn). Jurnal Pendidikan Kewarganegaraan, 7(1), 91-103. http://103.123.108.111/handle/123456789/426.

Schulz, W., Ainley, J., Fraillon, J., Kerr, D., \& Losito, B. (2010). ICCS 2009 International Report: Civic Knowledge, Attitudes, and Engagement among Lower-Secondary School Students in 38 Countries. International Association for the Evaluation of Educational Achievement. http://eric.ed.gov/?id=ED520018.

Soapatty, L. (2014). Pengaruh Sistem Sekolah Sehari Penuh (Full Day School) Terhadap Prestasi Akademik Siswa SMP Jati Agung Sidoarjo. Kajian Moral Dan Kewarganegaraan, 2(2), 719-733.

Sofyan, F. S., \& Sundawa, D. (2016). Hubungan Mata Kuliah Pendidikan Kewarganegaraan Dengan Peningkatan Wawasan Kebangsaan Dan Semangat Nasionalisme Mahasiswa. Jurnal Pendidikan Ilmu Sosial, 24(2), 185. https://doi.org/10.17509/jpis.v24i2.1455.

Supriyadi, E. (2015). Pendidikan dan Penilaian Karakter di Sekolah Menengah Kejuruan. Jurnal Cakrawala Pendidikan, 2. https://doi.org/10.21831/cp.v0i2.7590.

Suyatno, S., \& Wantini, W. (2018). Humanizing the Classroom: Praxis of Full Day School System in Indonesia. International Education Studies, 11(4), 115. https://doi.org/10.5539/ies.v11n4p115.

Torney-Purta, J. (2002). The school's role in developing civic engagement: A study of adolescents in twenty-eight countries. Applied Developmental Science, 6(4), 203-212. https://doi.org/10.1207/S1532480XADS0604_7. 
Torney-Purta, J., Cabrera, J. C., Roohr, K. C., Liu, O. L., \& Rios, J. A. (2015). Assessing Civic Competency and Engagement in Higher Education: Research Background, Frameworks, and Directions for Next-Generation Assessment. ETS Research Report Series, 2015(2), 1-48. https://doi.org/10.1002/ets2.12081.

Trisiana, A. (2020). Penguatan pembelajaran pendidikan kewarganegaraan melalui digitalisasi media pembelajaran. Jurnal Pendidikan Kewarganegaraan, 10(2), 31-41. https://ppjp.ulm.ac.id/journal/index.php/pkn/article/view/9304.

Winataputra, U. S., \& Budimansyah, D. (2007). Civic Education: Konteks, Landasan, Bahan Ajar dan Kultur Kelas. UPI. 